\title{
Analisis Integrasi Pasar Spasial Harga Daging Sapi di Provinsi Jambi
}

\author{
Bayu Krisna*, Firmansyah**, Fachroerrozi Hoesni** \\ *Alumni Magister Ilmu Peternakan Universitas Jambi \\ ** Staf Pengajar Magister Ilmu Peternakan Universitas Jambi \\ Correspondence e-mail : bayukrisna906@gmail.com
}

\begin{abstract}
This study aims to analyze the spatial market integration of beef prices in supporting the stabilization of prices for basic livestock products in Jambi Province. Spatial Market Integration Analysis Beef prices in Jambi Province use secondary data which is weekly time series data for the period 2018 - 2021 (August). The data analyzed in this study is the price of beef in the markets of Jambi City and Bungo Regency. The analytical method used to see the level of spatial integration of the beef market in supporting the stabilization of livestock staples both in the short and long term in Jambi Province is the VAR (Vector Autoregression) / VECM (Vector Error Correction Model) model. The study concludes that the weekly average beef price in Jambi City and Bungo Regency during the period 2018 to 2021 (August) is cointegrated. There is a long-term relationship between weekly average beef prices in Jambi City and Bungo Regency. The VECM model is more accurate in forecasting the weekly average beef price in Jambi City and Bungo Regency in the future.
\end{abstract}

\section{Keywords : Beef Price, Market Integration, VAR/VECM}

\section{Pendahuluan}

Pemerintah Daerah Provinsi Jambi memiliki kewajiban mengendalikan ketersediaan daging sapi sebagai barang kebutuhan pokok hasil peternakan baik jangka pendek maupun jangka panjang di seluruh wilayah Provinsi Jambi dalam jumlah yang memadai, mutu yang baik, dan harga yang terjangkau. Barang kebutuhan pokok hasil peternakan menurut Peraturan Pemerintah Nomor 71 tahun 2015 salah satunya adalah daging sapi. Selama satu dekade terakhir, daging sapi selalu memberi andil terjadinya peningkatan inflasi di Provinsi Jambi. Penelitian Darma et al., (2018) dan Rizaldy (2017) serta Setiawan dan Hadianto (2014) menginformasikan bahwa variasi harga komoditas pangan ternyata memberikan dampak atau pengaruh terhadap inflasi. Kebijakan stabilisasi harga barang kebutuhan pokok hasil peternakan khususnya daging sapi sulit untuk diimplementasikan secara efektif dan efisien. Hal tersebut dikarenakan: Pertama, wilayah yang sangat luas akan menyulitkan proses distribusi daging sapi; Kedua, ketidakseimbangan antara produksi dan konsumsi atau supply dan demand daging sapi; dan Ketiga, terdapat gap yang jauh antara pasar konsumen dengan daerah produksi yang menyebabkan biaya transportasi lebih mahal sehingga dapat membuat integrasi pasar daging sapi menjadi lemah. Implementasi kebijakan stabilisasi harga daging sapi oleh Pemerintah Pusat dan Daerah Provinsi Jambi akan lebih efektif terjadi pada pasar terintegrasi dibandingkan dengan pasar yang tidak terintegrasi. Menurut Arnanto dkk (2014) pada pasar yang terintegrasi, penerapan kebijakan stabilisasi harga barang pangan membutuhkan biaya yang lebih murah karena dapat didistribusikan kepada pasar-pasar lainnya. Tingkatan integrasi pasar menjadi bahan informasi yang penting bagi Pemerintah Daerah, dengan demikian jika terjadi lonjakan harga daging sapi di suatu kabupaten/kota maka segera dilakukan program aksi yang efektif untuk menghindari gejolak harga tidak meluas sampai tingkat provinsi maupun nasional.

Analisis integrasi pasar dilakukan untuk menguji keterpaduan harga antarpasar. Dengan mengukur tingkat integrasi pasar dapat dilihat efisiensi pasar secara spesifik (Ravallion 1986; Muwanga dan Snyder 1997; Meyer dan Taubadel 2004; Vasciaveo et al. 2013). Manfaat integrasi pasar bagi produsen dan pelaku pasar lainnya adalah supaya tidak ada pihak yang dirugikan terutama produsen dan konsumen. Jika suatu pasar terintegrasi dengan baik maka tingkat kerugian di pihak produsen dapat diminimalisir dan dapat mengurangi tindakan menyimpang dari pihak pedagang perantara. Dengan demikian diharapkan dapat memberikan keuntungan yang adil bagi setiap pihak yang terlibat dalam proses pemasaran (Zainuddin dkk, 2015; Nuraeni et al, 2015).

\section{Metode}

Analisis Integrasi Pasar Spasial Harga daging Sapi di Provinsi Jambi menggunakan data sekunder yang merupakan data time series mingguan dengan periode tahun 2018 - 2021 (Agustus). Data yang dianalisis dalam penelitian ini adalah harga daging sapi antara (pasar angso duo dan pasar talang banjar), dengan Pasar bungur dan seroja di Kabupaten Bungo yang bersumber dari Pusat Informasi Harga Pangan Strategis Nasional. Metode Analisis yang digunakan untuk melihat tingkat integrasi pasar spasial daging sapi dalam mendukung stabilisasi barang kebutuhan pokok hasil peternakan baik jangka pendek maupun jangka panjang di Provinsi Jambi digunakan model VAR (Vector Autoregression)/VECM (Vector Error Correction Model). Model yang digunakan untuk mengatasi ketidakstasioner data adalah model VEC (Vector Error Correction), dimana model ini akan mengkoreksi secara bertahap adanya ketidakseimbangan tersebut (Rosadi, 2012). 
Tahapan pengolahan data dengan menggunakan model VAR/VECM adalah :

1) Uji Stationeritas atau Unit Root Test diantaranya: (a) Untuk data time series dilakukan uji stasioneritas pada yang disebut stationary stochastic process. Kestasioneran diperlukan untuk menghindari adanya spurious regression (regresi palsu). Suatu persamaan dikatakan stasioner apabila memiliki mean, variance, dan covariance yang konstan pada setiap lag dan tidak mengandung akar-akar unit (unit root) . (b) uji stasioneritas data ini dapat dilakukan dengan menggunakan Augmented Dickey-Fuller (ADF) pada derajat yang sama (level atau different) hingga diperoleh suatu data yang stasioner, yaitu data yang variansnya tidak terlalu besar dan mempunyai kecenderungan untuk mendekati nilai rata-ratanya (Enders, 1995); dan (c) pengujian akar-akar unit dilakukan guna menganalisis apakah suatu variabel stationer atau tidak stationer. Widarjono (2013) menjelaskan bahwa fungsi uji ADF adalah untuk melihat ada tidaknya tren di dalam pergerakan data yang akan diuji. Uji ADF dirumuskan :

$\Delta P_{t}=\propto_{0}+\gamma P_{t-1}+\beta_{i} \sum_{j=1}^{m} \Delta P_{t-1}+\varepsilon_{i}$

dimana: $\mathrm{P}_{\mathrm{t}}=$ Harga Daging Sapi di setiap tingkat pasar pada periode $\mathrm{t}(\mathrm{Rp} / \mathrm{kg}) ; \mathrm{P}_{\mathrm{t}-1}=$ Harga Daging Sapi di setiap

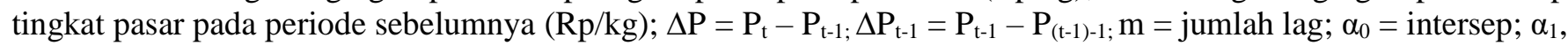
$\beta, \gamma=$ koefisien parameter; $\varepsilon_{\mathrm{t}}=$ error term

Pengujian hipotesis:

$\mathrm{H}_{0}: \gamma=0$ (data runtun waktu tidak stasioner)

$\mathrm{H}_{0}: \gamma<0$ (data runtun waktu stasioner)

Kaidah pengujian: 1) Jika ADF statistik > ADF kritis, maka tolak $\mathrm{H}_{0}$, artinya data runtun waktu tidak mengandung akar unit yang berarti bahwa data sudah stasioner; dan 2) Jika ADF statistik $\leq$ ADF kritis, maka terima $\mathrm{H}_{0}$, artinya data runtun waktu mengandung akar unit yang berarti bahwa data tidak stasioner.

2) Penentuan Lag Optimum, diantaranya: a) Panjang lag yang optimal diperlukan untuk melihat pengaruh dari setiap variabel terhadap variabel lain dalam model VAR. Nilai dari lag suatu variabel dapat berpengaruh terhadap variabel lainnya dikarenakan dibutuhkan waktu bagi suatu variabel untuk merespon pergerakan dari variabel lainnya. Penentuan panjangnya lag optimal digunakan kriteria, yaitu: Akaike Information Criteria (AIC); b) Dalam penentuan lag optimal dengan menggunakan kriteria informasi tersebut, kriteria yang dipilih adalah kriteria yang mempunyai jumlah dari AIC yang paling kecil di antara berbagai lag yang dianjurkan. Bila semakin kecil nilai kriteria tersebut, maka nilai harapan yang dihasilkan oleh sebuah model akan semakin mendekati kenyataan. Penentuan selang atau lag optimal merupakan tahapan yang penting dalam pendekatan VAR/VECM. Hal ini dikarenakan selang dari variabel endogen dalam sistem persamaan VAR/ VECM akan digunakan sebagai variabel eksogen. Penjangnya selang atau lag dari variabel yang optimal diperlukan untuk menangkap pengaruh variabelvariabel lainnya (Widarjono, 2013).

3) Uji Kointegrasi (Johansen Cointegration Test), diantaranya: a) Uji kointegrasi bertujuan untuk menentukan apakah variabel-variabel yang tidak stationer terkointegrasi atau tidak. Kombinasi linear ini dikenal dengan istilah persamaan kointegrasi dan dapat diinterpretasikan sebagai hubungan keseimbangan jangka panjang di antara variabel (Firdaus dan Gunawan, 2012); b) Pengujian kointegrasi dalam penelitian ini menggunakan pendekatan uji Johansen. Uji Johansen dilakukan dengan membandingkan antara nilai trace statistic dengan nilai critical value dan maximum eigenvalue dengan critical value pada taraf nyata 5\%. Jika trace statistic atau maximum eigenvalue lebih besar dari critical value maka mengindikasikan bahwa dalam sistem persamaan terdapat hubungan jangka panjang atau kointegrasi; dan c) Pengambilan keputusan dilakukan dengan melihat nilai trace statistic dan critical value. 1) Jika trace statistic > critical value, maka tolak $\mathrm{H}_{0}$ atau terima $\mathrm{H}_{1}$ yang artinya terjadi kointegrasi.; 2) Jika tidak terdapat kointegrasi antar variabel maka digunakan model VARD (VAR in difference), sedangkan jika dalam data yang diduga di model VAR terdapat kointegrasi maka model VAR yang digunakan adalah model VECM (Vector Error Correction Model) (Firdaus dan Gunawan, 2012).

4) Uji Kausalitas Granger, diantaranya: a) Uji kausalitas Granger dilakukan untuk melihat hubungan kausalitas di antara variabel-variabel yang ada dalam model. Pengujian hubungan sebab akibat, dalam pengertian Granger (1969), dengan menggunakan F-test untuk menguji apakah lag informasi dalam variabel Y memberikan informasi statistik yang signifikan tentang variabel $\mathrm{X}$ dalam menjelaskan perubahan $\mathrm{X}$. Jika tidak, maka $\mathrm{Y}$ tidak ada hubungan sebab akibat Granger dengan X (Firdaus dan Gunawan, 2012); b) Apabila pengujian dengan menggunakan metode Granger test menunjukkan bahwa hubungan kausalitas terjadi dua arah (harga daging sapi domestik mempengaruhi harga daging sapi dunia, dan sebaliknya).

5) Estimasi Model VAR/VECM, diantaranya: a) Vector Error Correction Model (VECM) merupakan model VAR yang teretriksi yang digunakan untuk variabel yang tidak stationer tetapi memiliki potensi untuk terkointegrasi. Setelah pengujian kointegrasi pada model yang digunakan, maka dianjurkan untuk memasukkan persamaan kointegrasi ke dalam model yang digunakan. Pada data time series kebanyakan memiliki tingkat stationeritas pada perbedaan pertama (first difference) atau I(1) (Firdaus dan Gunawan, 2012); b) Model VAR dapat disusun setelah 
variabel-variabel dilihat kestasionerannya, kointegrasi, kelambanan, dan kecocokan variabel untuk dimasukkan dalam model. Berdasarkan penjelasan dari model VAR yang dilakukan oleh Widarjono (2013) dan Enders (1995), dapat diasumsikan model VAR kelambanan satu. Jika terdapat kointegrasi pada data yang dicek kestasionerannya maka model yang digunakan adalah model VECM (Vector Error Correction Model) lag p rank r.; dan c) VECM merupakan bentuk VAR yang teretriksi. Retriksi tambahan ini harus diberikan karena keberadaan bentuk data yang tidak stationer pada level, tetapi terkointegrasi. VECM kemudian memanfaatkan informasi retriksi kointegrasi tersebut ke dalam spesifikasinya. Oleh karena itu, VECM sering disebut sebagai desain VAR bagi series nonstationer yang memiliki hubungan kointegrasi.

\section{Hasil}

Uji stasioneritas data penelitian ini digunakan untuk mengkaji apakah data harga daging sapi rataan mingguan pada pasar tradisional di Kota Jambi selama periode tahun $2018 \mathrm{~s} / \mathrm{d} 2021$ (Agustus) mengandung akar-akar unit atau tidak. Data yang tidak stasioner akan menghasilkan estimasi parameter yang semu (spurious regression). Bila regresi semu ini diinterpretasikan akan menghasilkan analisis yang salah yang berakibat pada salahnya kebijakan yang diambil (Widarjono, 2013). Metode Augmented Dickey Fuller (ADF) adalah metode untuk pengujian unit root dengan cara membandingkan nilai $\mathrm{ADF}_{\text {statistik }}$ dengan nilai Mackinnon critical value masing-masing sebesar $1 \%, 5 \%$, dan $10 \%$. Hasil uji stasioneritas data harga daging sapi rataan mingguan di Kota Jambi dan Kabupaten Bungo selama periode tahun 2018 s/d 2021 (Agustus). Berdasarkan pengujian unit root pada tingkat level atau I(0) didapat hasilnya yaitu harga daging sapi di Kota Jambi memiliki nilai $\mathrm{ADF}_{\text {statistik }}(-3.062271)$ lebih kecil dari critical value $1 \%$ (-3.465780) dan probabilitasnya signifikan pada tingkat keyakinan $1 \%(0.0312)$. Hal ini berarti data harga daging sapi di Kota Jambi belum stasioner pada tingkat level. Selanjutnya pengujian unit root pada tingkat level atau I( 0 ) didapat hasilnya yaitu harga daging sapi di Kabupaten Bungo memiliki nilai $\mathrm{ADF}_{\text {statistik }}(-2.424338)$ lebih kecil dari critical value $1 \%$ (3.465780) dan probabilitasnya signifikan pada tingkat keyakinan $1 \%(0.1365)$. Hal ini berarti data harga daging sapi di Kabupaten Bungo belum stasioner pada tingkat level. Pengujian stasionaritas data ini penting dilakukan, karena biasanya data time series mengandung akar unit. Akar unit ini dapat menyebabkan regresi yang signifikan secara statistik dan nilai koefisien determinasi yang tinggi, namun hubungan antar variabel didalam model tidak saling berhubungan (Widarjono, 2013).

Apabila dari uji ini ternyata data belum stasioner maka pengujian dilakukan lagi dengan data turunan kedua. Dengan model yang sama, dengan menggunakan data turunan kedua Pt dan data turunan pertama untuk Pt-1, selanjutnya dilakukan uji derajat integrasinya: jika $\beta=1$ maka variabel $P$ stasioner pada derajat satu. Oleh karena harga daging sapi di Kota Jambi belum stasioner pada tingkat level, maka dilanjutkan pengujian unit root pada tingkat first difference didapat hasilnya yaitu harga daging sapi di Kota Jambi memiliki nilai $\mathrm{ADF}_{\text {statistik }}(-13.36799)$ lebih besar dari critical value $1 \%(-3.465780)$ dan probabilitasnya signifikan pada tingkat keyakinan $1 \%(0.00000)$. Hal ini berarti data harga daging sapi di Kota Jambi telah stasioner pada first difference. Kemudian harga daging sapi di Kabupaten Bungo dilanjutkan pengujian unit root pada tingkat first difference sehingga diperoleh nilai $\mathrm{ADF}_{\text {statistik }}(-$ 12.82039) lebih besar dari critical value $1 \%$ (-3.465780) dan probabilitasnya signifikan pada tingkat keyakinan $1 \%$ (0.00000). Hal ini berarti data harga daging sapi di Kabupaten Bungo telah stasioner pada first difference. Suatu data time series dikatakan stasioner pada tingkat level atau I (0) jika nilai uji t lebih besar dari nilai kritis pada taraf nyata 5 persen. Ketika data tidak stasioner pada tingkat level maka perlu dilakukan proses diferensiasi, yaitu dengan mengurangi data tersebut dengan data periode sebelumnya (Ajija, dkk. 2011).

Tabel 1

Hasil Uji Stasioneritas Harga Daging Sapi di Kota Jambi dan Kabupaten Bungo

\begin{tabular}{|c|c|c|c|c|c|c|}
\hline No & Level & Persamaan Uji (Trend \& Intercept) & t-Statistic & Augmented & ical values & Prob.* \\
\hline \multirow{6}{*}{1.} & \multirow{6}{*}{ Harga Daging Sapi di Kota Jambi } & \multirow{3}{*}{ Level } & \multirow{3}{*}{-3.062271} & $1 \%$ Level & -3.465780 & \multirow{3}{*}{0.0312} \\
\hline & & & & $5 \%$ Level & -2.877012 & \\
\hline & & & & $10 \%$ Level & -2.575097 & \\
\hline & & \multirow{3}{*}{ First difference } & \multirow{3}{*}{-13.36799} & $1 \%$ Level & -3.465780 & \multirow{3}{*}{0.0000} \\
\hline & & & & $5 \%$ Level & -2.877012 & \\
\hline & & & & $10 \%$ Level & -2.575097 & \\
\hline \multirow{6}{*}{2.} & \multirow{6}{*}{ Harga Daging Sapi di Kab. Bungo } & \multirow{3}{*}{ Level } & \multirow{3}{*}{-2.424338} & $1 \%$ Level & -3.465780 & \multirow{3}{*}{0.1365} \\
\hline & & & & $5 \%$ Level & -2.877012 & \\
\hline & & & & $10 \%$ Level & -2.575097 & \\
\hline & & \multirow{3}{*}{ First difference } & \multirow{3}{*}{-12.82039} & $1 \%$ Level & -3.465780 & \multirow{3}{*}{0.0000} \\
\hline & & & & $5 \%$ Level & -2.877012 & \\
\hline & & & & $10 \%$ Level & -2.575097 & \\
\hline
\end{tabular}

Sumber: data olahan 
Tabel 2

Hasil Uji Lag Optimal Harga Daging Sapi di Kota Jambi dan Kabupaten Bungo

\begin{tabular}{lllllll}
\hline & Lag & LogL & LR & FPE & AIC & SC \\
\hline 0 & -3423.656 & NA & $3.41 \mathrm{e}+13$ & 36.83501 & 36.86970 & 36.84907 \\
\hline 1 & -3388.044 & 70.07598 & $2.42 \mathrm{e}+13$ & 36.49509 & 36.59915 & 36.53726 \\
\hline 2 & -3375.461 & $24.48941^{*}$ & $2.21 \mathrm{e}+13^{*}$ & $36.40280^{*}$ & $36.57623^{*}$ & $36.47308^{*}$ \\
\hline
\end{tabular}

Sumber: data olahan

Hasil uji lag optimal untuk harga daging sapi rataan mingguan di Kota Jambi dan Kabupaten Bungo selama periode tahun 2018 s/d 2021 (Agustus) menunjukkan bahwa lag 2 adalah lag yang optimal (terlihat dari tanda bintang). Penggunaan lag 2 sebagai lag yang optimal pada model artinya dari sisi ekonomi berimplikasi bahwa harga daging sapi rataan mingguan di Kota Jambi dan Kabupaten Bungo saling mempengaruhi satu sama lain tidak hanya pada periode sekarang, tetapi harga daging sapi rataan mingguan di Kota Jambi dan Kabupaten Bungo saling berkaitan pada dua periode sebelumnya. Penentuan lag optimal berguna untuk melihat seberapa lama suatu variabel bereaksi terhadap variabel lainnya dan menghindari kemungkinan autokorelasi residual pada sistem VAR (Firdaus dan Gunawan, 2012).

Untuk mengetahui integrasi pasar spasial daging sapi dalam jangka panjang di Provinsi Jambi dilakukan uji kointegrasi. Uji yang dilakukan adalah trace test yaitu mengukur jumlah vektor kointegrasi dalam data dengan menggunakan pengujian pangkat matriks kointegrasi (Enders 1995). Jika tidak terdapat kointegrasi antar variabel maka digunakan model VARD (VAR in difference), sedangkan jika dalam data yang diduga di model VAR terdapat kointegrasi maka model VAR yang digunakan adalah model VECM (Firdaus dan Gunawan, 2012). Pada penelitian ini, uji kointegrasi dilakukan dengan menggunakan metode Johansen's Cointegration Test.

Tabel 3

Hasil Uji Kointegrasi Harga Daging Sapi di Kota Jambi dan Kabupaten Bungo

\begin{tabular}{|c|c|c|c|c|}
\hline Hypothesized No. of CE(s) & Eigenvalue & Trace Statistic & 0.05 Critical Value & Prob.** \\
\hline None ${ }^{*}$ & 0.101113 & 29.42494 & 20.26184 & 0.0021 \\
\hline At most $1^{*}$ & 0.050292 & 9.597801 & 9.164546 & 0.0414 \\
\hline Hypothesized No. of CE(s) & Eigenvalue & Max-Eigen Statistic & 0.05 Critical Value & Prob.** \\
\hline None ${ }^{*}$ & 0.101113 & 19.82713 & 15.89210 & 0.0114 \\
\hline At most $1^{*}$ & 0.050292 & 9.597801 & 9.164546 & 0.0414 \\
\hline
\end{tabular}

Sumber: data olahan

Berdasarkan hasil uji kointegrasi, terlihat bahwa nilai Trace Statistic lebih besar dari nilai kritis 5\%. Selain itu, nilai Max-Eigen juga lebih besar nilai kritis 5\%, maka dapat disimpulkan bahwa harga daging sapi rataan mingguan di Kota Jambi dengan Kabupaten Bungo terkointegrasi. Semakin besar nilai trace statistic dan maksimum eigenvalue maka semakin tinggi tingkat kointegrasinya (Jojo dkk., 2021). Kointegrasi adalah hubungan yang terjadi antar variabel-variabel yang stasioner pada derajat yang sama. Kointegrasi ini merupakan alat analisis ekonometrika yang dapat menunjukkan keseimbangan jangka panjang antara variabel yang sangat erat berhubungan sebagai alat peramalan, maka dari itu stasioneritas data perlu dilakukan sebagai syarat penting dalam pengujian pendekatan kointegrasi (Maruddani dkk, 2008).

Terjadinya kointegrasi artinya pasar daging sapi Kota Jambi dan Kabupaten Bungo atau terjadinya intergrasi pasar daging sapi Kota Jambi dan Kabupaten Bungo dalam jangka panjang akan menguntungkan karena perubahan (kenaikan atau penurunan) harga daging sapi di Kota Jambi akan ditransmisikan ke pasar daging sapi di Kabupaten Bungo sehingga terjadi keseimbangan dalam jangka panjang, yaitu terdapat kesamaan pergerakan dan stabilitas hubungan diantara harga daging sapi rataan mingguan di Kota Jambi dan Kabupaten Bungo. Menutut Fackler dan Goodwin (2001), sinyal dan informasi harga berada ditransmisikan secara merata sehingga pergerakan harga antara pasar yang berbeda akan sama. Integrasi pasar daging sapi adalah metode untuk melihat keterkaitan atau keterpaduan harga antar pasar di wilayah Provinsi Jambi. Fackler dan Goodwin (2001) menjelaskan integrasi pasar merupakan tingkat pergerakan harga pada daerah yang berbeda, dimana barang yang sama akan memiliki harga yang sama, meskipun dijual pada tempat yang berbeda, dan sinyal harga serta informasi pasar ditransmisikan secara merata (Ghosh, 2000). Pasar yang terintergasi mengindikasikan tentang sistem pemasaran yang efisien (Fadhla dkk., 2008), dimana akan terjadi korelasi yang positif dari waktu ke waktu antara harga di lokasi pasar yang berbeda (Heytens, 1986). Sehingga transmisi dan informasi diantara berbagai pasar menyebabkan harga bergerak bersamaan di berbagai pasar. Pasar yang tidak terintegrasi baik secara spasial maupun vertikal dapat mengindikasikan terjadi ketidakefisienan pemasaran sehingga mengakibatkan adanya permainan harga dan terjadinya distorsi harga di pasar (Barrett, 2005). Anindita (2004), lemahnya struktur pasar adalah konsekuensi dari lemahnya integrasi pasar, sulitnya informasi, dan aliran perdagangan di antar pasar. 
VECM mengukur bagaimana penyimpangan harga dapat kembali pada keadaan keseimbangan (Hendy dan Juselius, 2000). Jadi, VECM adalah kombinasi dari hubungan janga pendek dan jangka panjang antar variabel harga dari pasar yang berbeda (Nagubadi et al, 2001 dalam Irawan dan Rosmayanti, 2007).

Tabel 4

Hasil Estimasi Model VECM Harga Daging Sapi di Kota Jambi dan Kabupaten Bungo

\begin{tabular}{|c|c|c|c|}
\hline No & Error Correction: & D(KABBUNGO,2) & D(KOTA JAMBI,2) \\
\hline \multirow{3}{*}{1} & \multirow{3}{*}{ CointEq1 } & $0.433733^{* * * *}$ & $1.289578^{* * * *}$ \\
\hline & & $(0.09363)$ & $(0.10320)$ \\
\hline & & [4.63223] & {$[12.4959]$} \\
\hline \multirow{3}{*}{2} & \multirow{3}{*}{ D(KABBUNGO $(-1), 2)$} & $-1.204497^{* * * *}$ & $-0.898050^{* * * *}$ \\
\hline & & $(0.11005)$ & $(0.12130)$ \\
\hline & & {$[-10.9446]$} & {$[-7.40363]$} \\
\hline \multirow{3}{*}{$\beta$} & \multirow{3}{*}{$\mathrm{P}(\mathrm{KABBUNGO}(-2), 2)$} & $-0.562803^{* * * *}$ & $-0.438320^{* * * *}$ \\
\hline & & $(0.08981)$ & $(0.09899)$ \\
\hline & & {$[-6.26643]$} & {$[-4.42800]$} \\
\hline \multirow{3}{*}{4} & \multirow{3}{*}{ D(KOTA JAMBI(-1),2) } & $0.618629^{* * * *}$ & $0.993510^{* * * *}$ \\
\hline & & $(0.15140)$ & $(0.16687)$ \\
\hline & & [4.08610] & {$[5.95392]$} \\
\hline \multirow{3}{*}{5} & \multirow{3}{*}{$\mathrm{P}(\mathrm{KOTA}$ JAMBI $(-2), 2)$} & $0.268502^{* * * *}$ & $0.435386^{* * * *}$ \\
\hline & & $(0.08681)$ & $(0.09568)$ \\
\hline & & {$[3.09305]$} & {$[4.55057]$} \\
\hline \multirow{3}{*}{6} & \multirow{3}{*}{$\mathrm{c}$} & -8.796600 & -8.552021 \\
\hline & & (196.497) & $(216.572)$ \\
\hline & & {$[-0.04477]$} & {$[-0.03949]$} \\
\hline
\end{tabular}

Sumber: data olahan

Berdasarkan hasil estimasi model VECM harga daging sapi rataan mingguan di Kota Jambi dan Kabupaten Bungo seperti tersaji pada Tabel 4. Adanya parameter error correction yang signifikan membuktikan adanya mekanisme penyesuaian harga daging sapi rataan mingguan dari jangka pendek ke jangka panjang. Besaran penyesuaian harga daging sapi rataan mingguan dari jangka pendek ke jangka panjang di Kabupaten Bungo yaitu sebesar 0,43\%, sedangkan besaran penyesuaian harga daging sapi rataan mingguan dari jangka pendek ke jangka panjang di Kota Jambi sebesar 1,29\%. Pasar yang terintergasi mengindikasikan tentang sistem pemasaran yang efisien (Fadhla, 2008), dimana akan terjadi korelasi yang positif dari waktu ke waktu antara harga di lokasi pasar yang berbeda (Heytens, 1986). Sehingga transmisi dan informasi diantara berbagai pasar menyebabkan harga bergerak bersamaan di berbagai pasar tersebut. Pasar yang tidak terintegrasi baik secara Pasar yang tidak terintegrasi baik secara spasial maupun intertemporal dapat mengindikasikan bahwa terjadi ketidakefisienan pemasaran sehingga mengakibatkan adanya permainan harga dan terjadinya distorsi harga di pasar (Barrett, 2005). Hal ini sejalan dengan pendapat Anindita (2004) bahwa lemahnyastruktur pasar adalah konsekuensi dari lemahnya integrasi pasar, sulitnya informasi, dan aliran perdagangan di antar pasar-pasar yang terpisah. Kecepatan dan ketepatan informasi harga akan mendorong tercapainya efisiensi dalam pengambilan keputusan alokasi sumberdaya. Kondisi tersebut menunjukkan bahwa keberadaan integrasi pasar sebagai salah satu indikator penting dalam efisiensi sistem pemasaran.

Pada Tabel 4. terlihat bahwa harga daging sapi di Kabupaten Bungo dipengaruhi oleh harga harga daging sapi di Kabupaten Bungo pada 1 minggu sebelumnya, dan dipengaruhi oleh harga daging sapi di Kota Jambi pada 1 dan 2 minggu sebelumnya. Harga harga daging sapi di Kabupaten Bungo dalam jangka pendek dipengaruhi oleh perubahan harga daging sapi di Kabupaten Bungo pada 1 minggu sebelumnya, besarnya perubahan sebesar 0,433. Dengan kata lain, jika terjadi perubahan (kenaikan) harga daging sapi di Kabupaten Bungo 1 minggu sebelumnya sebesar $1 \%$, maka akan terjadi perubahan (kenaikan) harga daging sapi di Kabupaten Bungo sekarang sebesar 0,433 \%. Koefisienkoefisien Error Correction Term (ECT) menggambarkan kecepatan penyesuaian per periode menuju keseimbangan Jangka panjang. Koefisien-koefisien ECT dalam VECM adalah ukuran kecepatan penyesuaian menuju hubungan keseimbangan jangka panjang antar pasar (Enders, 1995). Menurut Anwar (2005), kecepatan penyesuaian ditunjukkan oleh nilai absolut dari ECT, yang diinterpretasikan sebagai ketidakseimbangan antara harga aktual dengan tingkat keseimbangan jangka panjang. Semakin besar koefisien mengindikasikan cepatnya penyesuaian menuju keseimbangan jangka panjang dan sebaliknya. Gangguan perubahan harga periode sebelumnya pada beberapa pasar dalam model dapat diinterpretasikan sebagai penyesuaian jangka pendek sementara pasar ada dalam keseimbangan jangka panjang dengan pasar-pasar lainnya.

Selain itu, harga daging sapi di Kabupaten Bungo dalam jangka pendek dipengaruhi oleh perubahan harga daging sapi di Kota Jambi pada 1 dan 2 minggu sebelumnya, dengan perubahan masing-masing sebesar 0,62 dan 0,27. Artinya, jika terjadi perubahan (kenaikan) harga daging sapi di Kabupaten Bungo 1 dan 2 minggu sebelumnya sebesar $1 \%$, maka akan terjadi perubahan (kenaikan) harga daging sapi di Kota Jambi sekarang masing-masing sebesar $0,62 \%$ dan 0,27\%. Penjelasan lain adalah setiap minggu, harga daging sapi di Kota Jambi kesalahan dikoreksi sebesar 0,62 \% dan 0,27\% menuju keseimbangan jangka panjang harga daging sapi di Kabupaten Bungo. Tidak 
terjadinya integrasi pasar menunjukkan bahwa perubahan harga dalam satu pasar produsen tidak direfleksikan sebagai suatu perubahan harga di pasar produsen yang berbeda secara geografis (Goletti, dkk., 1995). Lebih lanjut pasar yang tidak terintegrasi ini akan menyebabkan alokasi sumberdaya yang tidak efisien (Faminow dan Benson 1990; Tahir dan Riaz 1997; Meyer dan Taubadel, 2004). Pasar yang tidak terintegrasi dapat membawa informasi yang tidak akurat sehingga dapat mendistorsi keputusan pasar produsen dan kontribusi pergerakan produk menjadi tidak efisien. Penelitian ini menemukan bahwa harga daging sapi di Kota Jambi Bungo dipengaruhi oleh harga harga daging sapi di Kota Jambi pada 1 minggu sebelumnya, dan dipengaruhi oleh harga daging sapi di Kabupaten Bungo pada 1 dan 2 minggu sebelumnya. Harga harga daging sapi di Kota Jambi dalam jangka pendek dipengaruhi oleh perubahan harga daging sapi di Kota Jambi pada 1 minggu sebelumnya, besarnya perubahan sebesar 0,99. Dengan kata lain, jika terjadi perubahan (kenaikan) harga daging sapi di Kota Jambi 1 minggu sebelumnya sebesar $1 \%$, maka akan terjadi perubahan (kenaikan) harga daging sapi di Kota Jambi sekarang sebesar 0,99\%. Selain itu, harga harga daging sapi di Kota Jambi dalam jangka pendek dipengaruhi oleh perubahan harga daging sapi di Kabupaten Bungo pada 1 dan 2 minggu sebelumnya, dengan perubahan masing-masing sebesar 0,89 dan 0,44. Artinya, jika terjadi perubahan (kenaikan) harga daging sapi di Kota Jambi 1 dan 2 minggu sebelumnya sebesar $1 \%$, maka akan terjadi perubahan (kenaikan) harga daging sapi di Kabupaten Bungo sekarang masing-masing sebesar 0,89\% dan 0,44\%.

Menurut Mayer dan Taubadel (2004), harga di antara dua pasar yang tidak bergerak dari satu pasar ke pasar lainnya, dapat disebabkan oleh: biaya penyesuaian, kekuatan pasar yang dimiliki pasar tertentu, kebijakan pemerintah dan informasi yang asimetris. Dengan demikian, untuk meningkatkan integrasi pasar broiler, perlu upaya peningkatan transmisi yang lebih baik dengan peningkatan akses informasi pasar secara transparan. Pasar yang terintegrasi mencerminkan transmisi harga yang simetris. Hal tersebut perlu didukung dengan tersedianya infrastruktur dan sarana informasi yang murah dan mudah diakses secara online. Terintegrasinya pasar daging sapi akan memberikan dampak pada distribusi margin pelaku usaha ternak sapi sehingga tercipta rasa keadilan semua pihak. Hal ini sejalan dengan pendapat Conforti (2004), bahwa transmisi harga dan integrasi pasar akan berjalan sempurna apabila di dalam pasar tidak terjadi friksi dan distorsi. Artinya, pasar akan berjalan secara efisien jika tidak terdapat gangguan-gangguan/ penyimpangan pada pasar, seperti jarak, peraturan (yang ketat/membatasi), dan biaya (overhead cost).

Tabel 5

Hasil Uji Kausalitas Granger Harga Daging Sapi di Kota Jambi dan Kabupaten Bungo

\begin{tabular}{cccrr}
\hline No & Null Hypothesis: & Obs & F-Statistic & Prob. \\
\hline 1 & KOTAJ AMBI does not Granger Cause KAB BUNGO & 187 & 0.42014 & 0.6576 \\
2 & KAB BUNGO does not Granger Cause KOTA JAMBI & & 0.18568 & 0.8307 \\
\hline
\end{tabular}

Sumber: data olahan

Hasil Uji kausalitas Granger (Granger Causality Test) disebutkan bahwa H0 menyatakan harga daging sapi di Kota Jambi tidak mempengaruhi harga daging sapi di Kabupaten Bungo. Berdasarkan nilai $\mathrm{F}_{\text {statistik }}$ sebesar 0,42014 dengan nilai probabilitas sebesar 0.6576 maka H0 diterima, yang berarti harga daging sapi di Kota Jambi tidak signifikan mempengaruhi harga daging sapi di Kabupaten Bungo. Selanjutnya hasil Uji kausalitas Granger (Granger Causality Test) yaitu bahwa H0 menyatakan harga daging sapi di Kabupaten Bungo tidak mempengaruhi harga daging sapi di Kota Jambi. Berdasarkan nilai $F_{\text {statistik sebesar }} 0,18568$ dengan nilai probabilitas sebesar 0.8307 maka H0 diterima, yang berarti harga daging sapi di Kabupaten Bungo tidak signifikan mempengaruhi harga daging sapi di Koata Jambi.

Analisis Impulse response dapat melacak respon dari variabel dependen dalam model VAR terhadap gangguan pada masing-masing variabel. Pada setiap variabel dari setiap persamaan yang berbeda, gangguan diterapkan pada error termnya sehingga dapat dilihat dampaknya pada model VAR dari waktu ke waktu. Teknik ini digunakan pada model VAR yang disebut dengan VMA, Vector Moving Average. Jika model stabil, maka secara bertahap gangguan akan hilang (Brooks, 2008). Analisis Impulse response diperlukan dalam estimasi VAR/VECM karena secara individual koefisien dalam model VAR/VECM sulit untuk diinterpretasikan. Fungsi dari impulse response adalah untuk melacak respon dari variabel endogen di dalam sistem VAR/VECM dikarenakan adanya gangguan atau perubahan di dalam variabel gangguan. Penggunaan impulse response dapat membantu peneliti untuk melacak guncangan untuk beberapa periode ke depannya (Widarjono, 2013). Berdasarkan analisis Impulse Response Function untuk harga daging sapi rataan mingguan di Kota Jambi dan Kabupaten Bungo terlihat bahwa respon harga daging sapi rataan mingguan di Kabupaten Bungo terhadap harga daging sapi rataan mingguan di Kota Jambi adalah rendah selama 10 periode. Namun respon harga daging sapi rataan mingguan di Kota Jambi terhadap harga daging sapi rataan mingguan di Kabupaten Bungo adalah tinggi pada awal periode kemudian menurun sampai ke 10 periode. 
Response of D(KABBUNGO) to D(KABBUNGO)

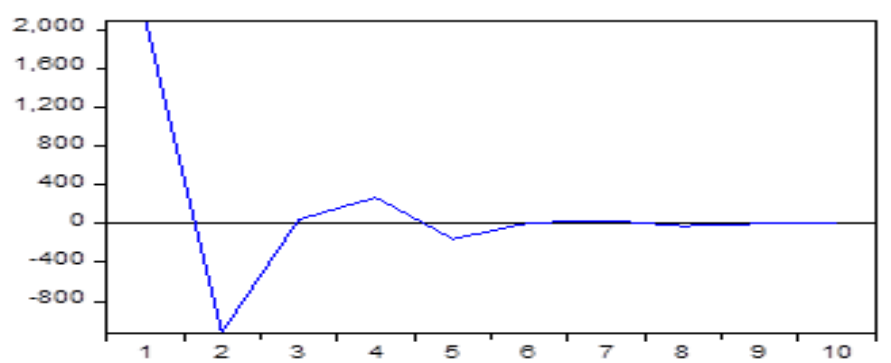

Response of D(KOTA.JAMBI) to D(KABBUNGO)

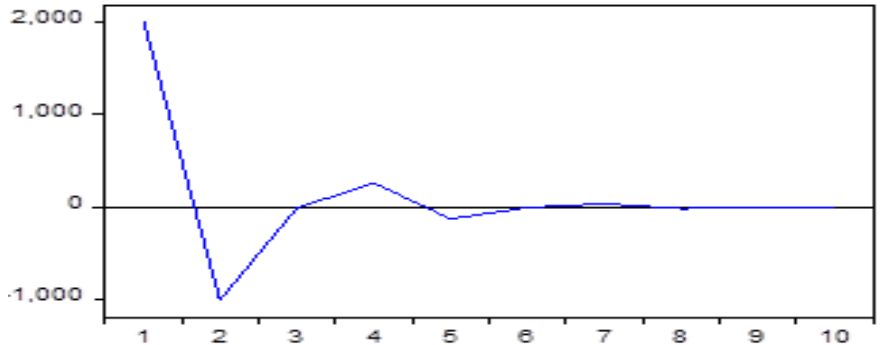

Response of D(KABBUNGO) to D(KOTAJAMBI)

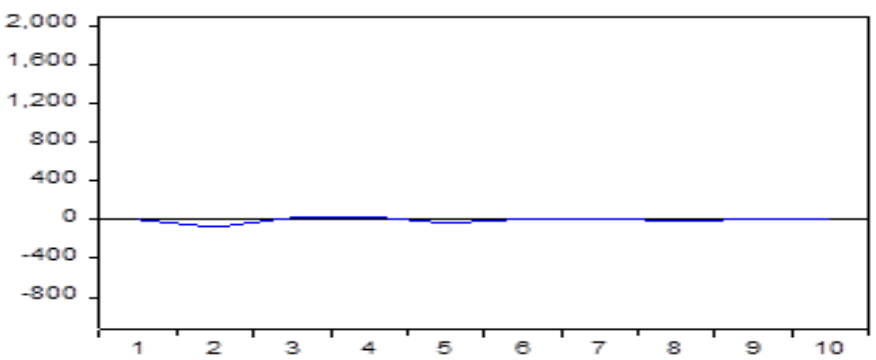

Response of D(KOTA.JAMBI) to D(KOTA.JAMBI)

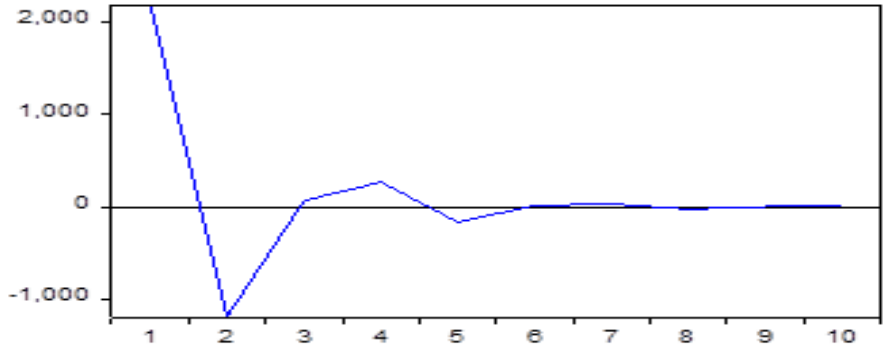

Sumber: data olahan

\section{Gambar 1}

Impulse Response Function

Variance decomposition digunakan untuk memprediksi kontribusi persentase varians setiap variabel karena adanya perubahan variabel tertentu di dalam sistem VAR (Widarjono, 2013). Proporsi pergerakan harga daging sapi rataan mingguan di Kabupaten Bungo yang disebabkan oleh gangguan pengaruh shock dari harga daging sapi rataan mingguan di Kabupaten Bungo pada periode pertama sebesar 100\% dan yang berasal dari pengaruh shock dari harga daging sapi rataan mingguan Kota Jambi tidak ada (0 \%). Pada periode ke dua, gangguan pengaruh shock dari harga daging sapi rataan mingguan di Kabupaten Bungo menurun menjadi 99,89\% sedangkan pengaruh shock dari harga daging sapi rataan mingguan Kota Jambi sebesar 0,10\%, keadaan tersebut terus berlanjut sampai periode ke 10

Tabel 6

Hasil analisis Variance Decompositions harga daging sapi Kota Jambi dan Kab. Bungo

\begin{tabular}{|c|c|r|r|}
\hline Variance Decomposition of D(KABBUNGO): Period & SE. & D(KABBUNGO) & D(KOTAJAMBI) \\
\hline 1 & 2097.333 & 100.0000 & 0.000000 \\
\hline 2 & 2380.025 & 99.89954 & 0.100455 \\
\hline 3 & 2380.563 & 99.89001 & 0.109986 \\
\hline 4 & 2396.314 & 99.87128 & 0.128718 \\
\hline 5 & 2401.637 & 99.85205 & 0.147948 \\
\hline 6 & 2401.675 & 99.85106 & 0.148936 \\
\hline 7 & 2401.946 & 99.85002 & 0.149976 \\
\hline 8 & 2402.053 & 99.84910 & 0.150899 \\
\hline 9 & 2402.055 & 99.84905 & 0.150950 \\
\hline 10 & 2402.060 & 99.84902 & 0.150982 \\
\hline Variance Decomposition ofD(KOTAJAMBI): Period & S.E. & D(KABBUNGO) & D(KOTA JAMBI) \\
\hline 1 & 2968.704 & 45.91346 & 54.08654 \\
\hline 2 & 3349.904 & 45.05467 & 54.94533 \\
\hline 3 & 3350.629 & 45.03647 & 54.96353 \\
\hline 4 & 3371.898 & 45.07890 & 54.92110 \\
\hline 5 & 3378.288 & 45.05221 & 54.94779 \\
\hline 6 & 3378.331 & 45.05119 & 54.94881 \\
\hline 7 & 3378.679 & 45.05256 & 54.94744 \\
\hline 8 & 3378.792 & 45.05191 & 54.94809 \\
\hline 9 & 3378.793 & 45.05188 & 54.94812 \\
\hline 10 & 3378.799 & 45.05191 & 54.94809 \\
\hline
\end{tabular}

Sumber: data olahan

Namun sedikit berbeda untuk proporsi pergerakan harga daging sapi rataan mingguan di Kota Jambi yang disebabkan oleh gangguan pengaruh shock dari harga daging sapi ratan mingguan di Kota Jambi pada periode pertama sebesar 55,09\% dan yang berasal dari pengaruh shock dari harga daging sapi rataan mingguan Kabupaten Bungo sebesar 45,91\%. Pada periode ke 10, gangguan pengaruh shock dari harga daging sapi rataan mingguan dari Kota Jambi sebesar 54,95\% sedangkan pengaruh shock dari harga daging sapi rataan mingguan Kabupaten Tebo sebesar $45,05 \%$. Setelah melakukan analisis terhadap hasil peramalan, langkah terakhir adalah melakukan uji validasi 
yaitu dengan menghitung nilai MSE dan mean absolute percentage error MAPE dari masing-masing variabel. Semakin kecil nilai MSE dan MAPE, maka semakin akurat hasil ramalan yang diperoleh.

Tabel 7

Nilai RMSE, MAE, MAPE, dan Theil

\begin{tabular}{|l|c|c|c|c|c|}
\hline \multicolumn{1}{|c|}{ Variable } & Inc. obs. & RMSE & MAE & MAPE & Theil \\
\hline KABBUNGO & 188 & 2068.951 & 721.9563 & 0.588589 & 0.008508 \\
\hline KOTAJAMBI & 188 & 2928.530 & 1060.115 & 0.853810 & 0.011908 \\
\hline
\end{tabular}

Sumber: data olahan

\section{Simpulan}

1. Harga daging sapi rataan mingguan di Kota Jambi dengan Kabupaten Bungo selama periode tahun 2018 s/d 2021 (Agustus) terkointegrasi. Terdapat hubungan jangka panjang antara harga daging sapi rataan mingguan di Kota Jambi dengan Kabupaten Bungo.

2. Harga daging sapi di Kabupaten Bungo dipengaruhi oleh harga harga daging sapi di Kabupaten Bungo pada 1 minggu sebelumnya, dan dipengaruhi oleh harga daging sapi di Kota Jambi pada 1 dan 2 minggu sebelumnya. Sedangkan harga daging sapi di Kota Jambi Bungo dipengaruhi oleh harga harga daging sapi di Kota Jambi pada 1 minggu sebelumnya, dan dipengaruhi oleh harga daging sapi di Kabupaten Bungo pada 1 dan 2 minggu sebelumnya

3. Model VECM lebih akurat dalam meramal harga daging sapi rataan mingguan di Kota Jambi dan Kabupaten Bungo periode ke depan

\section{Daftar Pustaka}

Ajija, Shochrul Rohmatul, dkk. 2011. Cara Cerdas Menguasai Eviews. Jakarta: Salemba Empat.

Anindita, R. 2004. Pemasaran Hasil Pertanian. Papyrus. Surabaya.

Anwar C. 2005. Prospek Karet Alam Indonesia di Pasar Internasional: Suatu Analisis Integrasi Pasar dan Keragaan Ekspor [disertasi]. Bogor: Program Pascasarjana, Institut Pertanian Bogor.

Arnanto, S. Hartoyo dan W. Rindayati. 2014. Analisis Integrasi Pasar Spasial Komoditi Pangan Antar Provinsi di Indonesia. Jurnal Ekonomi dan Kebijakan Pembanguan. 3(2),136-157

Barrett, C. 2005. Measuring Integration And Efficiency In International Agricultural Market. Review of Aricultural Economics. 23(1): 19-32.

Brooks, Chris. 2008. Introductory Econometrics for Finance. Cambridge University Press, New York.

Burhani FJ, Fariyanti A, Jahroh S. 2013. Analisis volatilitas harga daging sapi potong dan daging ayam broiler di Indonesia. Forum Agribis. 3(2):1939.

Conforti P. 2004. Price Transmission in Selected Agricultural Markets. Working Paper FAO Commoditiy and Trade Policy Research

Darma, D. C., Pusriadi, T., \& Hakim, Y. P. (2018). Dampak Kenaikan Harga Komoditas Sembako Terhadap Tingkat Inflasi di Indonesia. Prosiding Seminar Nasional: Manajemen, Akuntansi, dan Perbankan, 1048-1074.

Enders W. 1995. Applied econometric time series. New York (US): John Willey \& Sons.

Fackler, P. L., \& Goodwin, B. K. (2001). Spatial price analysis. Handbook of agricultural economics, 1, 971-1024.

Fadhla, T, B.A. Nugroho dan M.M. Mustajab. 2008. Integrasi Pasar Komoditi Pangan (Beras, Kacang Tanah Kupas Dan Kedelai Kuning) Di Propinsi Nanggroe Aceh Darussalam. Agritek, 16(9).

Faminow MD, Benson BL. 1990. Integration of Spatial Market. American Journal of Agricultural Economics, 72:4962

Firdaus M, Gunawan I. 2012. Integration among regional vegetable markets in Indonesia. J. ISSAAS. 18(2), 96-106.

Ghosh, M. 2000. Cointegration Test and Spatial Integration of Rice Market in India. Indian Journal of Agriculture Economics. 55(4), 616-625.

Goletti, F. and E. Christina-Tsigas. 1995. Analyzing market integration. In Scott, G. J. (Ed.). Prices, products and people: Analyzing agricultural markets in developing countries. International Potato Center

Hendy, D. F. and Juselius K. 2000. Explaining Co-integration Analysis: Part I, Energy Journal, 21, 44.

Heytens, J Paul. 1986. Testing Market Integration. Food Research Institute Studies, XX(1).

Irawan, A. dan Rosmayanti, D. 2007. Analisis Integrasi Pasar Beras di Bengkulu. Jurnal Agro Ekonomi, 25(1), 37 54.

Jojo, Harianto, R. Nurmalina dan D.B. Hakim. 2021. Integrasi Pasar Ayam Broiler di Sentra Produksi di Jawa Barat dan Pasar Indonesia. Pangan, 30(1), 31 - 44

Maruddani, Di Asih I., Tarno dan Anisah, Rokhma Al. 2008. Uji Sasioneritas Data Inflasi dengan Phillips-Peron Test. Media Statistik,1(1), 27-34.

Meyer JS, Taubadel VC. 2004. Asymmetric price transmission: a survey. J Agric Econ. 55(2004):581-611. 
Muwanga GS, Snyder DL. 1997. Market integration and the law of one price: case study of selected feeder cattle markets. Economic Research Institute Study Paper. Paper 122. Utah (US): Utah State University.

Nuraeni, D., R. Ardhiani dan Syafrial. 2015. Analisis Variasi Harga dan Integrasi Pasar Bawang Merah di Jawa Barat. Jurnal Habitat, 26(3).163-172.

Ravallion, M. 1986. Testing Market Integration. American Journal of Agricultural Economics. 68(1), 102-109.

Rizaldy, D. . (2017). Pengaruh Harga Komoditas Pangan Terhadap Inflasi di Kota Malang Tahun 2011-2016. Jurnal Ekonomi Pembangunan, 15(2).

Rosadi, D. 2012. Ekonometrika dan Analisis Runtun Waktu Terapan dengan Eviews. Yogyakarta : Andi Offset

Setiawan, A. F., \& Hadianto, A. (2014). Fluktuasi Harga Komoditas Pangan dan Dampaknya Terhadap Inflasi di Provinsi Banten. Jaree, 1(2).

Tahir Z. Riaz K. 1997. Integration of Agricultural Commodity Markets in Punjab. The Pakistan Development Review. 36 (3): 241-262.

Vasciaveo M, Rosa F, Weaver R. 2013. Agricultural market integration: price transmission and policy intervention. Presentation paper at the 2nd AIEAA Conference between Crisis and Development: which Role for the BioEconomy; 2013 Jun 6-7; Parma, Italy

Widarjono A. 2013. Ekonometrika: pengantar dan aplikasinya. Ed ke-4. Yogjakarta (ID): UPP STIM YKPN.

Zainuddin A., R. W Asmarantaka, dan Hariant. 2015. Integrasi Harga Daging Sapi di Pasar Domestik dan Internasional. Buletin Ilmiah Litbang Perdagangan, 9(2) 